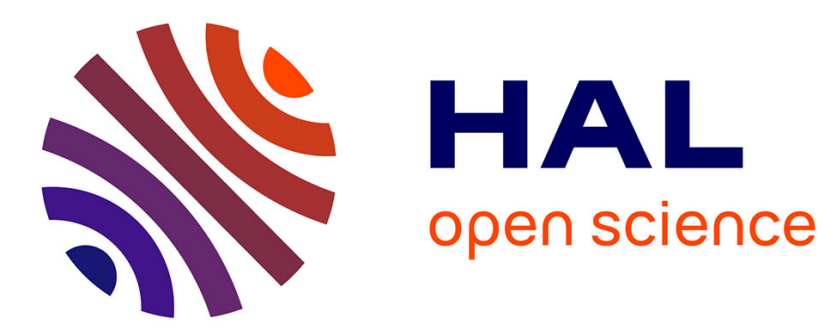

\title{
Sensorless and Robust PEMFEC Power System Drive based on $\mathrm{Z}(\mathrm{Tn})$ observability
}

Imen Mrad, Mohamed Derbeli, Lassaad Sbita, Jean-Pierre Barbot, Maissa

Farhat, Oscar Barambones

\section{- To cite this version:}

Imen Mrad, Mohamed Derbeli, Lassaad Sbita, Jean-Pierre Barbot, Maissa Farhat, et al.. Sensorless and Robust PEMFEC Power System Drive based on Z(Tn)observability. International Conference on Green Energy Conversion Systems, Mar 2017, Hammamet, Tunisia. hal-01710673

\section{HAL Id: hal-01710673 \\ https://hal.science/hal-01710673}

Submitted on 16 Feb 2018

HAL is a multi-disciplinary open access archive for the deposit and dissemination of scientific research documents, whether they are published or not. The documents may come from teaching and research institutions in France or abroad, or from public or private research centers.
L'archive ouverte pluridisciplinaire HAL, est destinée au dépôt et à la diffusion de documents scientifiques de niveau recherche, publiés ou non, émanant des établissements d'enseignement et de recherche français ou étrangers, des laboratoires publics ou privés. 


\section{Sensorless and Robust PEMFEC Power System Drive based on $\mathrm{Z}(\mathrm{Tn})$ observability}

\author{
Imen Mrad \\ National Engineering School of Gabes, \\ dept. electric-automatic \\ University of Gabes, Tunis. \\ Email: imenmrading@gmail.com
}

Jean Pierre Barbot

Professor of Universities at ENSEA

Director of QUARTZ EA 7393 ENSEA, 6

Avenue du Ponceau 95014, Cergy Pontoise, France Email: barbot@ensea.fr

\author{
Mohamed Derbeli \\ National Engineering School of Gabes, \\ dept. electric-automatic \\ University of Gabes, Tunis. \\ Email: derbelimohamed1@gmail.com \\ Maissa Farhat \\ Department of Electrical, Electronics and \\ Communications Engineering, American \\ University of Ras Al Khaimah, U.A.E \\ Email: maissa.farhat@gmail.com
}

\author{
Lassaad Sbita \\ National Engineering School of Gabes, \\ dept. electric-automatic \\ University of Gabes, Tunis \\ Email: lassaad.sbita@gmail.com
}

Oscar Barambones

Escuela Universitaria de Ingenieria

dept. Ingenieria de Sistemas y Automatica

Universidad del Pais Vasco, Vitoria, spain

Email: oscar.barambones@ehu.es

\begin{abstract}
In this paper, a robust Sliding Mode Controller (SMC) is applied to Proton Exchange Membrane Fuel Cell power system (PEMFC) to keep this latter working at its maximum operating power point, DC/DC interleved boost converter (IBC) is used in conjunction with the fuel cell generator for obtaining an efficient conversion from the PEMFC stack to the load. In order to minimize the number of sensors, a hybrid observer is applied to the IBC for reconstructing the system parameters values. However this particular switched system induces a difficult observability problems, such problem can be solved by a new observability concept called $Z(T N)$-observability. The proposed hybrid observer is based on a homogeneous observer coupled with an estimator. The performance of the proposed SMC and hybrid observer are validated by simulation studies in MATLAB/Simulink and results are discussed.
\end{abstract}

Keywords- PEMFC, SMC, IBC, Z(Tn)-observability, homogeneous observer

\section{INTRODUCTION}

Recently, there has been significant environmental and political motivation to replace traditional sources of energy by renewable ones such as wind, solar, geothermal and fuel cells. Fuel cells are considered as one kind of the most promising power generators. Hence, they have received a considerable attention from many researchers. Fuel cells are static electric power sources that convert the chemical energy of fuel into electrical energy. Hydrogen fuel is the most common fuel used for many cells due to its abundance in the earths surface and its low contamination. Besides, the release of greenhouse gases is reduced. However, other fuels such as alcohols and natural gas are sometimes used. Several types of fuel cells are used in the literature, such as, molten carbonate fuel cell (MCFC), alkaline fuel cell (AFC), solid oxide fuel cell (SOFC), phosphoric acid fuel cell (PAFC), direct methanol fuel cell (DMFC) and proton exchange membrane fuel cell (PEMFC). The advantages and disadvantages of each type of fuel cell are described in [1]. The performance characteristics such as high efficiency, high power density, low temperature (fast start up), quiet operation, zero levels of produced pollutant gases, system robustness and flexible modular structure, has caused the PEMFC to be the most popular type of fuel cells and the best candidate for a wide range of applications [1] [2]. In most applications, a circuit model would be beneficial if the PEMFC is used in conjunction with other power conditioning converters. Hence, the application of power converters can be used for obtaining an efficient conversion from the PEMFC stack to the load. According to Luo and Ye [3], more than 500 different topologies of power converter can be used in different applications. The most simple are the buck, the boost, the buck-boost and the interleaved boost converter .

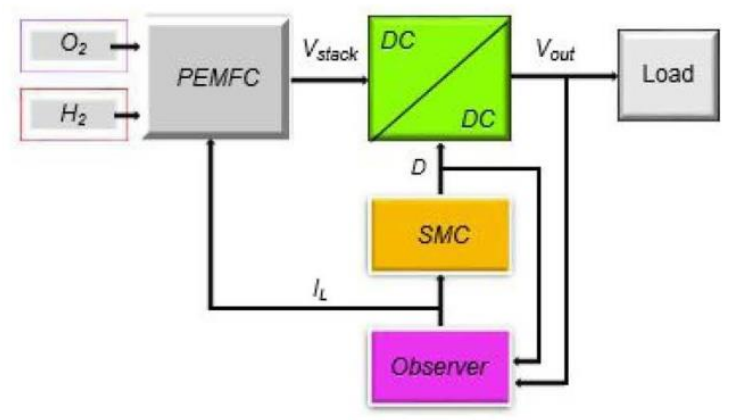

Fig. 1: Fuel cell operation diagram.

Thus, they provide a dc output voltage controlled with pulse width-modulation PWM switching technique. However, due to the law output voltage of the PEMFC, DC/DC interleaved boost converter can be used to transform the power from the fuel cell to the load in an appropriate form by virtue of their benefics. Among these advantages, interleaving techniques include reduced device stress by separating power into each discrets phases [4], reduced filter size by increasing effective frequency, and alleviation of the effects of current ripple [5]. Moreover, the ability to operate the converter when a failure 
occurs in one cell as well as possibility to add new cells to the converter with minimum efforts. In order to have more efficient conversion of power from the PEMFC stack to the load, several control methods have been used to keep the system working on the maximum power point (MPP). Classical linear control methods are commonly used in the control design for the interleaved boost converters. However, due to its nonlinearity, the linear control methods are not effective especially in the presence of large disturbances. Nowdays, unconventional techniques such as feedback linearizationmethods [5], Fuzzy Logic Controller (FLC) [6] [7] and Sliding Mode Controller (SMC) [8] [9] have been widely used in the literature. Sliding Mode Control or also known as Variable Structure Controller (VSC) has recently attracted considerable attention from many researchers due to several advantages [10], such as, its capability to stabilize the system against large parameter variations and load disturbances [11] [12], its implementation simplicity, high robustness, good behavior and great performance in a wide range of applications. Thus, it has been successfully applied to underwater vehicles, robot manipulators[13], automotive transmissions and engines [14]. In order to control DC DC IBC, a measuremant device is required. The use of observers and parametric estimators to reduce the number of sensors and to improve the robustness of controls is therefore largely longed for. Waveforms of current values were reconstructed. The purpose is to obtain the main physical quantities of this converter with a minimum of well positioned sensors. Thus, a hybrid observer for interleaved boost converter is proposed. However, the state vector of interleaved boost converter is not observable, at any time; except depending on certain conditions, there exists the so-called hybrid time trajectory [15], after which it can reconstruct the state vector. In this paper, such conditions can be presented through the recently concept $\mathrm{Z}(\mathrm{Tn})$-Observability [16]. In this context, two observrs are proposed based on the homogenous observer alghorithm [17] coupled with an estimator. The paper is organised as follows: Section 2 describes the PEMFC and the IBC models; Section 3 presents the proposed sliding mode controller for controlling a DC/DC IBC; Section 4 is devoted to the analysis of a hybrid observability of IBC using the concept of $\mathrm{Z}(\mathrm{TN})$ observability and the observer design. To illustrate the theoretical results, simulation results are presented in Section 5. Finally, a conclusion is given in Section 6.

\section{PEMFC MOdEL AND INTERLEAVEd Boost CONVERTER MODELLING}

\section{A. PEMFC Model}

Proton exchange membrane fuel cells (PEMFC) are a power generation devices that directly converts chemical energy into electric energy by a chemical reaction. According to Fig.2, a PEMFC is composed of two electrodes separated by an electrolyte. The basic principle of the PEMFC is an electrochemical power generation devices for producing electricity from hydrogen and oxygen, this can be expressed simply by the electrochemical reaction as shown in the following equations.

Anode reaction: $2 \mathrm{H}_{2} \Longrightarrow 4 \mathrm{H}^{+}+4 e^{-}$

Cathode reaction: $\mathrm{O}_{2}+4 \mathrm{H}^{+}+4 e^{-} \Longrightarrow 2 \mathrm{H}_{2} \mathrm{O}$

Overall reaction: $2 \mathrm{H}_{2}+\mathrm{O}_{2} \Longrightarrow 2 \mathrm{H}_{2} \mathrm{O}+$ E.E

Hydrogen is fed to the anode and splits into its primary constituents, protons and electrons. The electrolyte which acts like a membrane permits only the positive ions (protons) to flow from anode to cathode and acts as an insulator for negative ions (electrons). Therefore, Protons travel through the membrane, while the electrons travel through the external circuit to generate elecricity and return to the other side of the membrane where they meet with protons migrating through the membrane and oxygen that is fed to the cathode. Water and heat are created as the product of the electrochemical reaction. The PEMFC output voltage as a function of current

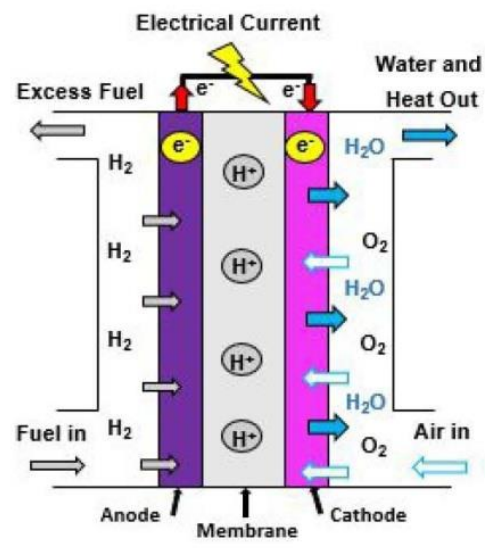

Fig. 2: Fuel cell operation diagram.

can be represented by the $I-V$ polarization curve of Fig.3, which is influenced by several parameters such as oxygen and hydrogen partial pressure, the cell ambient temperature, and membrane water content. The cell voltage $V_{\text {cell }}$ is given in equation (1), where $E_{\text {cell }}$ represents the open circuit voltage and its equation is given in (2), $\eta_{a c t}, \eta_{o h m}$ and $\eta_{c o n}$ are respectively the activation loss, the ohmic loss, and the concentration loss. The activation loss (wich given in equation (3)) is the voltage drop due to the activation of the anode and the cathode. This phenomenon is strongly nonlinear and more important at low current. The ohmic loss (wich given in equation (4)) is caused by the resistance of the polymeric membrane to the passage of ions through the electrolyte and the resistance to the transport of electrons through the electrodes. The behavior of $\eta_{o h m}$ is approximately linear with the current. The concentration loss (wich given in equation (5)) is the result of increasing in the reactants concentration which caused by the diffusion of ions $\mathrm{H}^{+}$through the electrolyte. This effect is caused to an important voltage drop at high current.

$$
\begin{gathered}
V_{F c}=E_{\text {Cell }}-\eta_{\text {act }}-\eta_{\text {ohm }}-\eta_{\text {con }} \\
E_{\text {Cell }}=\frac{\Delta G}{2 F}-\frac{\Delta S}{2 F}\left(T-T_{\text {ref }}\right)+\frac{R T}{2 F}\left[\ln \left(P_{H 2}\right)\right.
\end{gathered}
$$




$$
\begin{gathered}
\left.+\frac{1}{2} \ln \left(P_{O 2}\right)\right] \\
\eta_{a c t}=\xi_{1}+\xi_{2} \cdot T+\xi_{3} \cdot T \cdot \ln \left(C_{O 2}\right)+\xi_{4} \cdot T \cdot \ln (I) \\
\eta_{\text {ohm }}=I \cdot\left(R_{m}+R_{c}\right) \\
\eta_{\text {con }}=B \cdot \ln \left(1-\frac{J}{J_{\max }}\right)
\end{gathered}
$$

Where, $\Delta S$ is the change of entropy of the reaction $(\mathrm{J} / \mathrm{mol})$, $\Delta G$ is the change in the free Gibbs energy of the reaction $(J / \mathrm{mol}), T$ and $T_{\text {ref }}$ are respectively the cell operating and the standard temperature $(298 K), P_{H_{2}}$ and $P_{O 2}$ represents respectively, hydrogen and oxygen partial pressures, $R$ is the universal constant of the gases $(\mathrm{J} / \mathrm{mol} . \mathrm{K}), I$ is the cell current in [A], $J$ is the current density passing through the cell at each moment $\left(\mathrm{A} / \mathrm{cm}^{2}\right), \xi_{(1-4)}$ are the parametric coefficients defined on the basis of kinetic, thermodynamic and electrochemical phenomena, $R_{c}$ is the proton resistance considered as a constant, $R_{m}$ and $C_{O 2}$ are respectively the equivalent resistance of the electron flow and the oxygen concentration, their valus can be determined using the expressions given in [00].

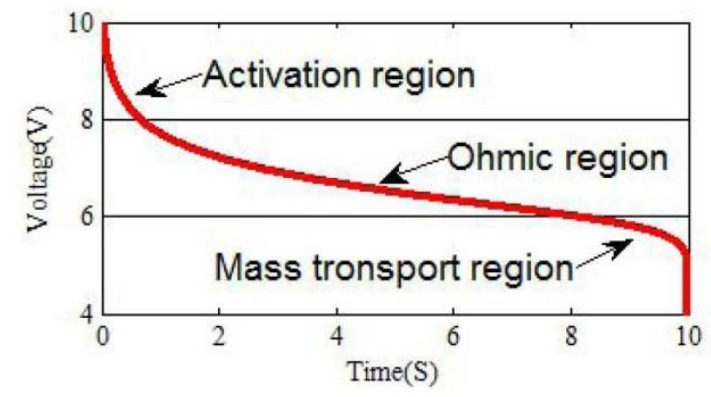

Fig. 3: I-V characteristic of PEMFC

\section{B. Interleaved Boost Converter Model}

To increase the conversion efficiency of the PEM Fuel cell power system, switching power system are widely used as DC/DC converters. Since the PEMFC power system requires a high step up DC/DC converter, the IBC can be used. This last consists of two single Boost converters connected in parallel. As shown in Fig. 4, it consist of two magnetizing inductances $L_{1}$ and $L_{2}$, an output capacitor $C$, semiconductor switches $q_{1}$ and $q_{2}$, two diodes $D_{1}$ and $D_{2}$ and a load resistor $R$, where $V_{i n}$ the input voltage, $i_{L_{1}}$ and $i_{L_{2}}$ are the inductors currents, $i_{C}$ and $V_{C}$ are the capacitor current and voltage respectively, $V_{\text {out }}$ the output voltage.

This circuit is assumed to operate under continuous conduction mode (CCM). Under such assumption, the circuit cyclically loops through two topologies. IBC operation can be illustrated on Fig. 4. The switch $q_{1}$ is turned $\mathrm{ON}$ first, so the inductor current $i_{L_{1}}$ increases linearly and at the same time energy is stored in inductor $L_{1}$. Then when $q_{1}$ is turned OFF, diode $D_{1}$ conducts and the stored energy in the inductor $L_{1}$ decrease with a slope of difference in the input and output voltage. The

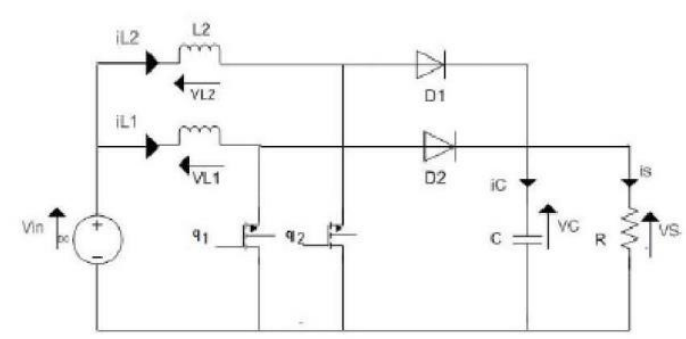

Fig. 4: Circuit of the IBC

inductor will discharges its energy through the diode to the load. Once half switching cycle $q_{1}$ is completed, $q_{2}$ is also turned $\mathrm{ON}$ and completed the same cycle of actions. Thus the slopes of the inductors currents are differents, therefore this provide a degree of freedom that can be used to minimize the amplitude of the current ripples.

The state space representation for the boost converter can be expressed by the following expression:

$$
\left\{\begin{array}{l}
{\left[\begin{array}{l}
\dot{x}_{1} \\
\dot{x}_{2} \\
\dot{x}_{3}
\end{array}\right]=\left[\begin{array}{ccc}
0 & 0 & -\frac{1-q_{1}}{L_{1}} \\
0 & 0 & -\frac{1-q_{2}}{L_{2}} \\
\frac{1-q_{2}}{C} & \frac{1-q_{1}}{C} & \frac{1}{R C}
\end{array}\right]\left[\begin{array}{l}
x_{1} \\
x_{2} \\
x_{3}
\end{array}\right]} \\
+\left[\begin{array}{lll}
\frac{1}{L_{1}} & \frac{1}{L_{2}} & 0
\end{array}\right]^{T} V_{i n} \\
y=\left(\begin{array}{lll}
0 & 0 & 1
\end{array}\right)\left[\begin{array}{lll}
x_{1} & x_{2} & x_{3}
\end{array}\right]^{T}=V_{s}
\end{array}\right.
$$

\section{Sliding MODE CONTROLLER (SMC)}

Sliding Mode controller has long been considered as a prefered approch for control of dynamic nonlinear systems. Hence, it ameliorate the dynamic system behavior. Moreover, the SMC is known to be a robust control approch appropriate for controlling uncertain systems. Thus, it shows good perfermonce when the system is required to operate in the presence of significant unknown variations. In this work, the SMC is used to drive the DC/DC boost converter for extracting the maximum power from the PEMFC by ensuring the actual current $x_{1}$ to tracks the desired current $x_{1 \text { ref }}$ which corresponding to the current of the maximum power point. According to [18], the sliding surface of the SMC can be given by the following equation.

$$
s(x, t)=\left(\frac{d}{d t}+\alpha\right)^{r-1} e(t)
$$

Where $e(t)$ is the tracking error , $r$ indicates the order of uncontrolled system, $\alpha$ is a positive constant. In order to enforce the sliding mode in the manifold $s(t)=0$, the corresponding control signal for an ideal switch can be given by the followng equation [19].

$$
u=\frac{1}{2}(1-\operatorname{sign}(s))
$$

The stability of a sliding mode controller can be verified by the Lyapunov equation which is illustrated in equation (8). This condition ensures the convergence of the operating point 
to the sliding surface by enforcing the state trajectory of the system to go towards the sliding surface $s(t)=0$ and slides over it. The demenstration of this condition can be found in [9]

$$
s . \dot{s}<0
$$

TABLE 1: Fuel cell model parameters.

\begin{tabular}{|c|c|c|}
\hline Symbol & Value & Unit \\
\hline$E_{0}$ & 1.229 & $\mathrm{~V}$ \\
$\mathrm{R}$ & 83.143 & $\mathrm{~J} \mathrm{~mol}^{-1} \mathrm{~K}^{-1}$ \\
$\mathrm{~F}$ & 96485.309 & $\mathrm{C} \mathrm{mol}$ \\
$\mathrm{T}$ & 298.15 & $\mathrm{~K}$ \\
$\Lambda$ & 162 & $\mathrm{~cm}^{2}$ \\
$\mathrm{~B}$ & 0.1 & $\mathrm{~V}$ \\
$R_{\mathrm{c}}$ & $3.10^{-1}$ & \\
$J_{m u \mathrm{c}}$ & 0.062 & $\mathrm{~A} \mathrm{~cm}$ \\
$\xi_{1}$ & 0.9514 & $\mathrm{~V}$ \\
$\xi_{2}$ & -0.00312 & $\mathrm{~V} / \mathrm{K}$ \\
$\xi_{3}$ & $-74.10^{-1}$ & $\mathrm{~V} / \mathrm{K}$ \\
$\xi_{4}$ & $187.10^{-2}$ & $\mathrm{~V} / \mathrm{K}$ \\
\hline
\end{tabular}

\section{OBSERVABILITY ANALYSIS AND OBSERVER DESIGN}

A. Observability analysis

Iet us consider the following class of system:

$$
\begin{aligned}
& \dot{\xi}=f_{q}(t, \xi, u), q \in Q,, \xi \in \Re^{n}, u \in \Re^{m} \\
& Y-h_{q}(t, \xi, u)
\end{aligned}
$$

Where $Q$ is a finite index sel, $f_{q}$ 沉 $\times \mathrm{r}^{n} \times \Re^{m} \rightarrow \mathrm{r}^{n}$ is sufficiently smooth, all dwell lime intervals, $\left[t_{i, 0}, t_{i, 1}\right]$, between two switchings of the structure satisfy $t_{i .1}-t_{i, 0}>\tau_{\min }$ for some $\tau_{\text {min }}>0$ (this assumption excludes 7eno phenomena [20]. For the input $u$ in any time interval $\left[t_{i, 0}, t_{i, 1}\left[\subseteq\left[t_{i n i} . t_{e n d}[\right.\right.\right.$, it assumed that $u(t)$ is bounded and sufficiently smooth.

For switched systems, the concept of observability and observer design are strongly related to the sequence of switching, thus it is important to recall the definition of hybrid time trajectory

Definition 1: [21] [15] A hybrid time trajectory is a finite or infinite sequence of intervals $T_{N}=\left(I_{i}\right)_{i=0}^{N}$, such that:

- $I_{i}=\mid t_{i, 0}, t_{i, 1}$, for $0 \leq i<N$;

- For all $i<N t_{i, 1}=t_{i \mid 1,0}$

- $t_{0,0}=t_{\text {ini }}$ et $t_{\mathrm{N}, 1}=t_{\text {end }}$

Moreover, $\langle T N\rangle$ is the ordered list of $q$ associated to $T N$

$\left(q_{0}, \ldots, q_{N}\right)$ with $q_{i}$ the value of $q$ during the time interval $I_{I}$ The concept of $Z(T N)$-Observability was proposed for non linears systems and switching systems. This notion has the particularity of taking into account the partial observability of the state and the hybrid time trajectory, the observability for each partial model and deduces the observability or unobservability with respect to switching sequence and the estimation of the parameters by a dynamic extension.

Definition 2: [16] Consider a system (1) and a variable $z-Z(t, \xi, u)$. Let $\left(t, \xi^{1}(t), u^{1}(t)\right)$ be a trajectory in $U$ with a hybrid time trajectory $T N$ and $\langle T N\rangle$. Suppose for any trajectory, $\left(t, \xi^{2}(t), u^{2}(t)\right)$, in $U$ with the same $T N$ and $\langle T N\rangle$, the equality:

$$
h\left(t, \xi_{1}(t), u_{1}(t)\right)=h\left(t, \xi_{2}(t), u_{2}(t)\right)
$$

implies

$$
Z\left(t, \xi_{1}(t), u_{1}(t)\right)=Z\left(t, \xi_{2}(t), u_{2}(t)\right)
$$

Then we say that $z-Z(t, \xi, u)$ is $Z(\mathrm{TN})$-observable along the trajectory $\left(t, \xi^{1}(t), u^{1}(t)\right)$.

\section{B. observability of the $I B C$}

Considering the observability matrix based on $q_{1}$ and $q_{2}$ of this hybrid system:

$$
d O(3)-\left[\begin{array}{ccc}
0 & 0 & 1 \\
\frac{1}{C}\left(1-q_{1}\right) & \frac{1}{C}\left(1-q_{2}\right) & -\frac{1}{R C} \\
a & b & c
\end{array}\right]
$$

Where:

$$
\begin{aligned}
& a=-\frac{1}{R C^{2}}\left(1-q_{1}\right) \\
& b=-\frac{1}{R C^{2}}\left(1-q_{2}\right) \\
& c=-\left(\frac{1}{L_{1} C}\left(1-q_{1}\right)^{2}+\frac{1}{L_{2} C}\left(1-q_{2}\right)^{2}\right)
\end{aligned}
$$

for $q_{1}=1$

$$
\left\{a-d-\frac{1}{C}\left(1-q_{1}\right)-0\right\}
$$

then $x_{1}$ is unobservable.

for $q_{2}=1$

$$
\left\{b=\epsilon=\frac{1}{C}\left(1-q_{2}\right)=0\right\}
$$

then $x_{2}$ is unobservable.

According to definition 1 and 2 , it can be said that the state $x_{1}$ is observable in the hybrid sense if at least the hybrid time trajectory containes one mode with $q_{1}=0$. The same for state $x_{2}$ is observable in the hybrid sense if at least the hybrid time trajectory containes one mode with $q_{2}=0$

\section{C. hybrid Observer design for the $I B C$}

The homogeneous observer [22] [17] used in this paper takes the following form:

$$
\begin{gathered}
\dot{\hat{z}}_{1}=\hat{z}_{1}-k_{1}\left\lceil\epsilon_{1}\right\rfloor^{\alpha_{1}} \\
\dot{\hat{z}}_{1}=\hat{z}_{1}-k_{2}\left\lceil e_{1}\right\rfloor^{\alpha_{2}} \\
\vdots \\
\dot{\hat{z}}_{{ }_{2}}-\hat{z}_{n-1}-k_{n}\left\lceil e_{1}\right\rfloor^{\alpha_{n}}
\end{gathered}
$$

where the function $\left[e_{1}\right\rfloor^{\alpha_{i}}=\left|e_{1}\right|^{\alpha} \operatorname{sign}\left(e_{1}\right)$ is defined as $e=z-\hat{z}$ tends to zero in finite time [17].

Thus the observation errors dynamics is given by:

$$
\left\{\begin{array}{l}
\dot{e}_{1}=\epsilon_{2}+\chi_{1}\left(\epsilon_{1}\right) \\
\dot{e}_{2}=\epsilon_{3}+\chi_{2}\left(\epsilon_{1}\right) \\
\vdots \\
\dot{e}_{n} 1=\epsilon_{n}+\chi_{n} \quad 1\left(e_{1}\right) \\
\dot{e}_{n}=\chi_{n}\left(e_{1}\right)
\end{array}\right.
$$

Let $\alpha_{1}-a$ 
Lemma 1: If $\alpha>1-\frac{1}{n-1}$ the system (12) is homogeneous of degree $\alpha-1$ with respect to the weights $\{(i-1) \alpha-(i-2)\}_{1 \leq i \leq n}$ and $\alpha_{i}=i \alpha_{1}-(i-1), 1 \leq i \leq n$.

Procf 1: For the proof see [17].

A hybrid observer is synthesized, which is characterized by two coupled modes of operation. The first mode is the observation of the states of the system based on a homogeneous observer, and the second is the estimate of the unobservable states by knowing their dynamic.

$\hat{f}\left\{\begin{array}{l}\dot{\hat{x}}_{1}=\frac{1}{L_{1}} V_{i n}-\frac{1}{L_{1}}\left(1-q_{1}\right) \hat{x}_{3}-k_{1}\left\lceil x_{3}-\hat{x}_{3}\right\rfloor^{\alpha}\left(1-q_{1}\right) \\ \dot{\hat{x}}_{2}=\frac{1}{L_{2}} V_{i n}-\frac{1}{L_{1}}\left(1-q_{2}\right) \hat{x}_{3}-k_{2}\left\lceil x_{3}-\hat{x}_{3}\right\rfloor^{2 \alpha-1}\left(1-q_{2}\right) \\ \dot{\hat{x}}_{3}=\frac{1}{C}\left(1-q_{1}\right) \hat{x}_{1}+\frac{1}{C}\left(1-q_{2}\right) \hat{x}_{2}-\frac{1}{R C} \hat{x}_{3} \\ -k_{3}\left\lceil x_{3}-\hat{x}_{3}\right\rfloor^{3 \alpha-2}\end{array}\right.$

\section{Simulation RESUlts}

In this section, sliding mode controller and hybrid observer for PEM Fuel cell power system are implimented in the Matlab Simulink environment. Simulations are carried out on a IBC circuit with the following parameter values: capacity $C=10^{-6} \mathrm{~F}$, inductors $L_{1}=L_{2}=1810^{-3} \mathrm{H}$ and resistor load $R=22 \mathrm{Ohm}$. The I-P and I-V characteristic of PEMFC were designed for $50 \mathrm{~W}$ with hydrogen and air are supplied at the atmospheric pressure equal to 0.6 bar, 0.0022 bar respectively and a temperature of $25 C^{\circ}$. It can bee seen from Fig. 5 that the power increases gradually to the maximum power point and then decreases. This model can producce $54 W$ as maximum power.

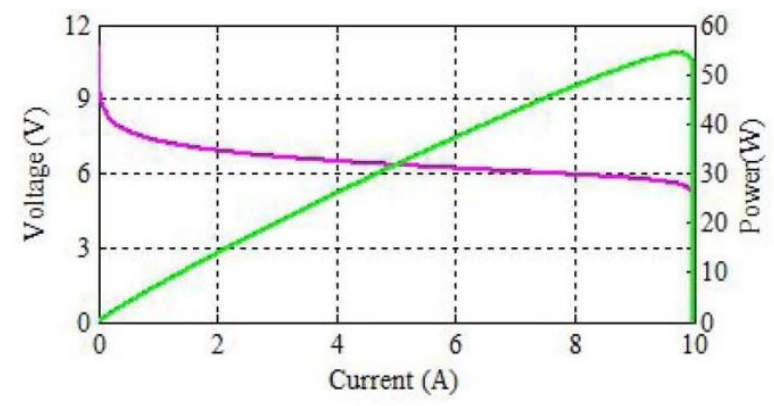

Fig. 5: Characteristics Curve of PEM Fuel Cell 10 Stack

To minimize the number of sensors in the circuit, the hybrid observer is designed. This latter reconstructed the inductor current value $\hat{i_{L}}$ which will be controlled by the SMC. Fig.6 ullistrates that the current $\hat{i_{L}}$ estimated by the observer converges in finite time to the real current value $i_{L}$. Thus, the developed observer allows to ensure sufficient observability even in the case where one of the sensors is inoperative. Fig.6 and Fig.7 prove that the sliding mode controller provides satisfactory results for tracking the reference value. Hence, the proposed controller shows gradual and smooth rise to the

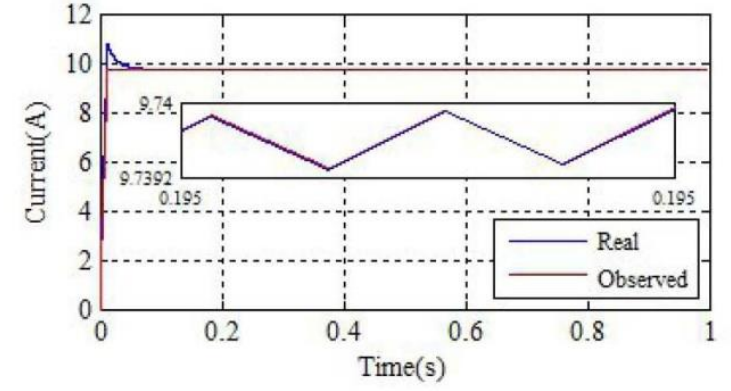

Fig. 6: PEM fuel cell observed current

reference value which corresponding to the maximum power point. Therefore, this exetensive simulation work is performed to prove a finite time convergence of the hybrid observer. Moreover, stability, robustness and good perfermances of the proposed controller are acheived.

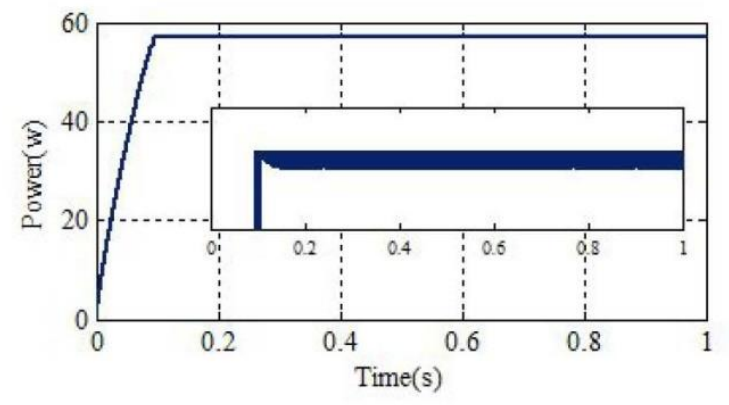

Fig. 7: PEM Fuel Cell Power

\section{CONCLUSION}

In this paper, a robust PEMFC Power System driving by sliding mode controller was presented. Furthermore, sensorless PEMFC Power System was building based on hybrid observer for the IBC. An extensive simulation work is performed to test the proposed observer structure and to prove the ability of the SMC for controlling the DC/DC IBC converter. The simulation results showed the finite time convergence of the homogeneous observer coupled with an estimator. Besides, this work demonstrates the capability of the proposed controller to keep the PEMFC operating at the MPP with high tracking performance and great robustness. It can be concluded that the proposed SMC is an efficient scheme in control systems, and the problem of unobservable configurations linked to particular switching sequences can be resolved by using the concept of $\mathrm{Z}(\mathrm{Tn})$-Observability.

\section{REFERENCES}

[1] J. M. Andújar and F. Segura, "Fuel cells: History and updating. a walk along two centuries," Renewable and sustainable energy reviews, vol. 13, no. 9, pp. 2309-2322, 2009.

[2] X. Zhang, J. Guo, and J. Chen, "The parametric optimum analysis of a proton exchange membrane (pem) fuel cell and its load matching," Energy, vol. 35, no. 12, pp. 5294-5299, 2010. 
[3] F. L. L. H. Ye, "Advanced dc/dc converters," 2004

[4] L. Ni, D. J. Patterson, and J. L. Hudgins, "High power current sensorless bidirectional 16-phase interleaved dc-dc converter for hybrid vehicle application," IEEE Transactions on Power Electronics, vol. 27, no. 3, pp. 1141-1151, 2012.

[5] P.-W. Lee, Y.-S. Lee, D. K. Cheng, and X.-C. Liu, "Steady-state analysis of an interleaved boost converter with coupled inductors," IEEE Transactions on Industrial Electronics, vol. 47, no. 4, pp. 787-795, 2000.

[6] G. Farivar, V. G. Agelidis, and B. Hredzak, "Fuzzy logic based control system for cascaded h-bridge converter," in Applied Power Electronics Corference and Exposition (APEC), 2014 Twenty-Ninth Annual IEEE, pp. 3006-3010, IEEE, 2014.

[7] L. Balezentiene, D. Streimikiene, and T. Balezentis, "Fuzzy decision support methodology for sustainable energy crop selection," Renewable and Sustainable Energy Reviews, vol. 17, pp. 83-93, 2013.

[8] S.-C. Tan, Y.-M. Lai, and C. K. Tse, "A unified approach to the design of pwm-based sliding-mode voltage controllers for basic dc-dc converters in continuous conduction mode," IEEE Transactions on Circuits and Systems I: Regular Papers, vol. 53, no. 8, pp. 1816-1827, 2006.

[9] M. Derbeli, M. Farhat, O. Barambones, and L. Sbita, "Control of pem fuel cell power system using sliding mode and super-twisting algorithms," International Journal of Hydrogen Energy, 2016.

[10] A. H. Alqahtani and V. I. Utkin, "Self-optimization of photovoltaic system power generation based on sliding mode control," in IECON 2012-38th Annual Corference on IEEE Industrial Electronics Society, pp. 3468-3474, IEEE, 2012.

[11] S.-C. Tan, Y. Lai, C. K. Tse, and M. K. Cheung, "An adaptive sliding mode controller for buck converter in continuous conduction mode," in Applied Power Electronics Corference and Exposition, 2004. APEC'04. Nineteenth Annual IEEE, vol. 3, pp. 1395-1400, IEEE, 2004.

[12] S.-C. Tan, Y. Lai, C. K. Tse, and M. K. Cheung, "Adaptive feedforward and feedback control schemes for sliding mode controlled power converters," IEEE Transactions on Power Electronics, vol. 21, no. 1, pp. $182-192,2006$

[13] A. Cid-Pastor, L. Martinez-Salamero, A. El Aroudi, R. Giral, J. Calvente, and R. Leyva, "Synthesis of loss-free resistors based on sliding-mode control and its applications in power processing," Control Engineering Practice, vol. 21, no. 5, pp. 689-699, 2013.

[14] O. López-Lapeña, M. T. Penella, and M. Gasulla, "A new mppt method for low-power solar energy harvesting," IEEE Transactions on Industrial Electronics, vol. 57, no. 9, pp. 3129-3138, 2010.

[15] J. Lygeros, K. H. Johansson, S. N. Simic, J. Zhang, and S. S. Sastry, "Dynamical properties of hybrid automata," IEEE Transactions on automatic control, vol. 48 , no. 1, pp. 2-17, 2003.

[16] W. Kang and J.-P. Barbot, "Discussions on observability and invertibility," IFAC Proceedings Volumes, vol. 40, no. 12, pp. 426-431, 2007.

[17] W. Perruquetti, T. Floquet, and E. Moulay, "Finite-time observers application to secure communication," IEEE Transactions on Automatic Control, vol. 53, no. 1, pp. 356-360, 2008.

[18] J.-J. E. Slotine, W. Li, et al., Applied nonlinear control, vol. 199. prentice-Hall Englewood Cliffs, NJ, 1991.

[19] V. Utkin, J. Guldner, and J. Shi, Sliding mode control in electromechanical systems, vol. 34. CRC press, 2009

[20] R. Goebel, J. Hespanha, A. R. Teel, C. Cai, and R. Sanfelice, "Hybrid systems: generalized solutions and robust stability," in Proc. 6th IFAC symposium in nonlinear control systems, pp. 1-12, 2004.

[21] R. Goebel, R. G. Sanfelice, and A. R. Teel, "Hybrid dynamical systems," IEEE Control Systems, vol. 29, no. 2, pp. 28-93, 2009.

[22] E. Bernuau, D. Efimov, E. Moulay, and W. Perruquetti, "Homogeneous continuous finite-time observer for the triple integrator," in Control Corference (ECC), 2015 European, pp. 903-908, IEEE, 2015. 